\title{
Welcoming Africa's children: The nature and implications of being a missional church
}



This article presents a brief overview of the historical development of the missional church from the understanding of the missio Dei. From this perspective, it attends to the African context. With regard to African children, the African independent churches are looked at from a missional church perspective. The nature of the missional church is described as being a Biblical, Trinitarian, discerning, evangelistic, hermeneutic and agogic community. The implication of being missional in accordance with the mentioned characteristics is then linked to the five solas of the Reformed tradition. It is concluded that the African independent churches and the mainline missionary churches need each other in order to be truly missional in Africa and to reach the children of Africa.

Intradisciplinary and/or interdisciplinary implications: Children and Youth Ministry is challenged by the context of Africa, when some relevant characteristics of the African independent or initiated churches (AICs) are described and related to the Reformed tradition. The (missional) ecclesiology of the AICs and the Reformed tradition is challenged by children's ministry.

\section{Introduction}

This article explores the nature and implications of being a missional church with a focus on Africa's children. According to Wright (2013:ix), the term 'missional' means 'to be characterised by mission'. The questions 'Whose mission?' and 'What is mission?' remain. In this article, the term 'missional' has a theological meaning in the sense that it refers to God's calling of the congregation in its local context, irrespective of the culture or conditions found in that context. It is the understanding that God has a church for his mission rather than a mission for his church. 'Missional church' is therefore something of a tautology, almost like 'female woman'; if a church is not missional, it is not church (Wright 2013:ix). Previously, it was said that if a church is not involved in missions, in other words, if it does not have mission activities, it is not a church. This article starts with an overview of the development of the 'missional church' concept before discussing the nature and implications of the missional church with reference to Africa's children.

\section{Background: Missio Dei}

The term 'missional' is a fairly new term and is used within a wide range of understandings, from describing a church that rejects treating the Gospel as a commodity by spiritual consumers to a strategy of marketing the church and stimulating church growth. Others see 'missional' as refocusing on God's actions in the world or meeting people where they are and reinventing the church in the postmodern culture (Billings 2008:56). In the second half of the 20th century, ecclesiology and missiology were profoundly influenced by the Trinitarian foundation of the missio Dei. The concept of a 'missional church' is also strongly influenced by the understanding of mission as missio Dei or 'the mission of God'. The danger is that 'missio Dei' is often used as an umbrella term to include almost everything. Engelsviken (2003:484-485) warns us that '[missio Dei] has been used by missiology ... as a comprehensive concept that includes almost everything the church is supposed to do, or, even more, what God is doing ...' and therefore lost its meaning. It is therefore important to clarify the understanding of missio Dei in this article.

The missio Dei as a theological concept emerged at the missiological conferences in the second half of the 20th century when profound political and social changes took place after two world wars and with the onset of decolonisation. It was also during this time that church and mission grew closer. Although the International Missionary Council was formed in Edinburgh in 1910, the World Council of Churches was only formed in 1948. At Willingen (Germany) in 1952, it was for the first time that a council of churches existed side by side with a missionary council. According to Anderson (1961:6), the question 'Why missions?' was asked at Willingen in 1952. Bosch (1991:370) 
indicates that the shift from a church-centred mission to a mission-centred church took place in 1938 at the International Missionary Council in Tambaran. It is here where the idea of the missio Dei surfaced clearly for the first time (Bosch 1991:390). This includes the understanding that the salvific work of God precedes both church and mission; the one is not subordinate to the other. The shift was from the church being the sender to the church being the one that has been sent. The church cannot save the world, but God can. Within this context of a broken world and church, the longing for God's involvement opened the minds to realise the influence of Barth's Trinitarian-based notion of the missio Dei (Ducker 2008:2-3). This Trinitarian founding of the missio Dei shifts the motivation of mission from ecclesiology and soteriology:

The classical doctrine on the missio Dei as God the Father sending the Son, and God the Father and the Son sending the Spirit was expanded to include yet another 'movement': Father, Son and Holy Spirit sending the church into the world. (Bosch 1991:390)

\section{This article concurs with Bosch (1991) that missio Dei is:}

God's self-revelation as the One who loves the world, God's involvement in and with the world, the nature and the activity of God which embrace both the church and the world, in which the church is privileged to participate. (p. 10)

Mission belongs to God in the same way that salvation belongs to God.

In 1961, the first joint conference between the International Missionary Council and the World Council of Churches was held in New Delhi. This evolution meant a momentous shift in the understanding of church and mission, and the World Council of Churches (WCC) authorised a study project on 'The Missionary Structure of the Congregation'. In 1967, at the next meeting of the WCC in Uppsala (Sweden), two reports served: one from the Western European Working Group and the other from the North American Working Group. Bosch (1991:382) comments that both reports had little to say about the 'missionary structure of the congregation', but that they had a profound influence on the meeting. The Europeans identified the goal of mission as 'shalom' and the North Americans identified it as 'humanization'. 'Mission' became an umbrella term; it was overtaxed with health and welfare, youth projects, economic and social development, and activities of political interest groups. 'The distinction between church and world has for all intends and purposes been dropped completely' (Bosch 1991:383).

In 1998, a multi-authored book, entitled Missional Church: A Vision for Sending the Church in North America, was the first book to introduce the concept 'missional church', bearing the missionary insights of Lesslie Newbigin (Billings 2008:56). Willem Saayman (2010:14-15) came to the conclusion that a distinctive characteristic of the term 'missional' is the clear

1.It seems that the absence of Martin Luther King at the conference and the politica context on racial issues in North America, as well as the political context of trade unions in Europe, influenced the different goals. relation to postmodern North Atlantic culture and emerging churches in postmodern contexts. The missional approach forms part of the renewed emphasis of the church's calling in its local context, from a 'Christendom model' focusing on internal needs to the needs of the community in which the church exists. As with the concept of missio Dei, it is the context, in this instance postmodernism, and the fact that church attendance in North America and Europe has declined that encourage theologians to think anew about the church. With the influence of the missio Dei and the understanding that the church exists for the mission of God (Bosch 1991:390; Wright 2013:ix), the opportunity opened towards a missional ecclesiology. With a declining church, it was no longer about the missions of the church (missiones ekklesia), but about God's mission with his church. According to Billings (2008):

Missional Church authors were not merely 'redesign[ing] the church for success in our changing context' or seeking a pragmatic 'method and problem solving' approach to ministry. Instead, they sought to diagnose the cultural captivity of today's church, including its obsession with marketing and technique. (p. 56)

For the purpose of this article, the term 'missional' is used to 'represent[s] a changed relationship between the church and its local context, one that calls for a renewed understanding of the church's identity in God' (Van Gelder \& Zscheile 2011:1). From this understanding of 'missional', the nature and implications of a missional church will be discussed.

\section{The nature and implications of a missional church Introduction}

Writing from a Western worldview and studying the possible influence on Africa's children ${ }^{2}$ when understanding the church as being missional, it is important to understand the African view on the church and on children. Describing the church as missional, meaning 'a changed relationship between the church and its local context' (Van Gelder \& Zscheile 2011:1), the African independent or initiated churches (AICs) will be used as example of the missional church in Africa. ${ }^{3}$ Oduro (2014:86) writes that the AICs have almost no mainstream missionary categories and dynamics. They do not have mission boards, they do not send missionaries, they do not organise mission conferences to emphasise the importance of mission and they do not have a mission budget. Yet, there are AIC congregations in almost every continent and in every state in Africa. 'AICs see little need to document their missionary nature, for they understand doing mission as the mandate of the church' (Oduro 2014:86). Bediako (1995:153) states that the impact of the Third World on the selfunderstanding of the church leads to 'a fuller concept of mission of the Church as embracing not only the ministry of

2.Discussing Africa's children, this article follows a homogenising system in which there is no room for an in-depth discussion of the unique and complex religious system of each group of people (cf. Adogbo 2005:76); children are viewed as those between the ages of 4 and 14 years.

3.The African independent churches include a wide variety of churches, from very close to the African traditional religion (ATR) and therefore very syncristic to, at the other end, very Biblical and Reformed churches. As it is not within the scope of this other end, very Biblical and Reformed churches. As it is not within the scope of this
article to describe the AICs as such, it will only focus on the missional characteristics of the AICs and use the term to describe the movement in general. 
the Word and the sacraments, but active involvement in economic and all human development' as well as the struggle for justice. It is clearly a missional understanding of the church in accordance with the definition in this article. Oduro (2014:86) continues to identify four concepts that shape AICs and contribute to their missional nature: First, every Christian is viewed as a missionary; second, training of missionaries is the responsibility of the Holy Spirit; third, Christians allow the Holy Spirit to direct the church to areas that are to be missionised; and fourth, a lack of money should not impede mission work (Oduro 2014:86-87). More attention will be given to these concepts at a later stage.

In contrast to the growth of the AICs, most Protestant mainline missionary churches (MMCs) 'whose cultures were once deeply influenced by various forms of Christendom are facing a crisis' (Zscheile 2012:1) of sharp decline in membership, participation and influence, not only in Europe and North America but also in Africa. With the disintegration of cultural Christianity, questions such as 'What kind of beliefs, practices and identities are functioning among those who profess Christian adherence?' are asked in the United States of America (Zscheile 2012:2). The same type of questions about the 'cultural Christianity of colonisation' needs to be answered in the MMCs in Africa, whose identities were mostly linked to the establishment. The MMCs in Africa and the AICs face challenging questions of discipleship formation of children in a decolonised Africa. Bediako (1995:154) uses arguments of Mbiti to show that there is no corresponding movement of 'mutuality and reciprocity in the theological task facing the universal church' in relation to the movement in Christian centres from the north to the south. It seems that although the church is becoming 'kerygmatically universal', it remains 'theologically provincial'. This is even truer regarding Children and Youth Ministry in Africa because there is no clear African theological understanding of children's ministry in Africa, especially among the AICs.

A further example of 'kerygmatically universal' but 'theologically provincial' is the fact that the MMCs will answer the question about the marks of a true church according to the catechisms in the following way: first, the proper preaching of the Gospel; second, the proper administration of the sacraments; and third, the proper use of discipline (Belgic Confession: Article 29). I agree with Allen's statement (2013:12) that there is an additional primary and predominant characteristic (namely the proper engagement in mission) that needs to be added to this understanding. The questions that should be answered are the following:

- What would 'the proper engagement in mission' entail for the MMCs in Africa? Who are working with a predominantly Western worldview?

- For what reasons does the church want to engage with the children of Africa?

- What or who does the church represent for the African child?

When answering these questions, at least the following characteristics must be part of the nature of the missional church in the African context.

\section{The Bible constitutes the missional church}

Wright (2006:22) clearly states that instead of talking about the Biblical basis of mission, it is preferable to talk about the missional basis of the Bible because the Bible not only contains a few texts that provide a rationale for mission, but 'the whole Bible is itself a "missional phenomenon"'. Both Wright (2006) and Schirrmacher (2013) go to great lengths to show the importance of the whole Bible, especially the Old Testament, in understanding God's mission. Discussing the literature of Paul, Schirrmacher (2013) stated:

However, if we look at the New Testament discussions about missions, we are astounded to realise that at that point where we would have quoted the Great Commission, it is the Old Testament that is almost always cited. (p. 54)

Wright (2006) clearly shows that the Great Commission is embedded in the covenant, and Schirrmacher (2013:54) sees the Great Commission as the fulfilment of the Old Testament. Thus, a missional church does not start with the Great Commission, but knows the story that they are part of, the story of God with his creation from beginning to end (Wright 2010:35-47). The missional church must engage with the children from Africa, not because of the Great Commission, but because God created them and declared them 'very good' (Gn 1:31; Ps 8; Ps 24; Ps 127; Ps 139).

In the MMCs, there is the highest respect for the Bible and the church is built on the revelation of God in the Bible. According to Oduro et al. (2008:113), this is not necessarily the same in the AICs. The AICs use the Bible everywhere, but it is not their only source of revelation. Personal revelation from or experience of God is in some instances viewed as just as important as the Bible:

In a sense, the whole AIC movement is based on the concept of the prophet. A prophet is a man or a woman upon whom the Spirit of God comes in a special way. (Oduro et al. 2008:113-114)

This perspective of the understanding of the missio Dei within the AICs refers back to the responsibility of the Spirit to train the missionary. Although the unique and important role of the Spirit in the missional understanding is not denied, it must be understood within the Trinitarian relationship (cf. Keum 2013).

\section{Biblical implications of being missional}

Turaki (2001:12) indicates that African theologians have spent too much time in cultural and religious studies; therefore, good theological and historical studies relating to the essentials of Biblical Christianity are lacking. On the other hand, Billings (2008:57) warns that whereas the missional church wants to free Scripture from cultural captivity, some kingdom theologies reduce the Gospel to a fashionable cultural creed of ethics, inclusion and social action. From the African context, Ndukwe (2011:136), a Nigerian, adds another perspective to this statement: "The theological mission ethics of the church are grounded in the Constantinian-Docetic as well as the Enlightenment-based 
visions of the Reformation eras. They yearn for modification'. In light of the above statements, the modification called for can only come when Scripture, the Sola Scriptura principle, is fundamental to the mission of the church. This must be further emphasised because it has been noted that the Bible is not the only authority in many AICs. Turaki (2001:3) comments that, in extreme cases, some African theologians argue that Christianity must abandon its 'Biblical and historical claims' that salvation is only found in Jesus Christ and accept the plurality of the means of salvation as found in other religions. Working with the Sola Scriptura principle, it is important to take note of Spyksman's distinguished:

five forms of God's Word: (1) his creative Word, which brought the world into existence; (2) his redeeming Word, spoken through the prophets; (3) his written Word, the Bible; (4) his Word incarnate, Jesus Christ; and (5) his Word of proclamation, in the preaching and teaching of the church. (Van der Walt 2008:15)

All five forms of the Word are exceptionally important for the missional church for obvious reasons because they are directly related to the missio Trinitatis Dei.

A missional church that is serious about the Bible as well as about (African) children will have to:

examine (selected) biblical texts through the 'lens' or category of 'the child'. In other words, they keep in mind or 'foreground' questions and concerns about children and childhood as they interpret biblical texts. (Bunge 2008:xviii)

In the book The Child in the Bible, edited by Bunge (2008), different Biblical perspectives on children and childhood are put forward by Biblical scholars. The focus on the child in the Bible seems to have been a neglected study for many years. This is even more so in Africa where, according to Turaki (2001), the focus is or was more on cultural and religious studies. Unfortunately, it is also true that children were, and in many instances still are, neglected in the mission thinking of the church (cf. Knoetze 2015a).

For centuries, children, especially in Africa, have been taught in Sunday school and catechism, 'learning the rules'. But teaching children about faith is more complex than only teaching the rules. Coming to faith is also about becoming part of and belonging to the church (cf. Miller 2008:45). As children inquire about God (Dean 2001:31), the church must equip them with the grand narrative of the Bible and let them realise that it is also their story. This involves questioning and knowing the story behind the rules and engaging in communal rituals and activities. This engagement with them is important in order for them to realise that the way in which God was involved in the lives of his people in the Bible is the same way in which God is involved in their own lives today. The church will do even better if it equips the African family in helping children to realise that they are part of the God story in the same way that they are part of their family's story.

\section{The missional church is Trinitarian based}

Barth has utilised a Western Trinitarian understanding that focused on the essential unity among the three Persons of the
Trinity and then proceeded to the distinct roles of the three Persons of God (Van Gelder \& Zscheile 2011:26). Heyns (1978:364-366) describes the creation of the church as follows: God the Father willed, elected, called and gathered the church. Sent by the Father, Jesus Christ is the origin (as fulfilment of the covenant), the confession, mission, head and message of the church. Sent by the Father and the Son, the Holy Spirit makes the church a unique community through building relations between man and Christ, man and the Kingdom of God, man and the Word of God, man and his neighbour, man and cosmos, and man and future (eschatology). According to Nurnberger (2007:47), the question is: 'Is there an African Trinitarian understanding, since spirituality in Africa is characterised by presence, and presence is determined by authority?' The historical Jesus and dogmatic Christ must become a living authority in concrete situations through the missional church in Africa. Myers (2011:59) argues that it is not enough to talk about who the Trinitarian God is; we must also talk about what he is doing. To know that Jesus is God is not enough to know him fully; we also need to know that he died for the sins of all humankind and provided for our forgiveness through his resurrection, but, more than that, that he conquered all evil forces at the cross (Col 2:14-15). This message and knowledge of his authority must be lived to make him known in Africa.

If a missional church is understood as 'a church whose identity lies in the participation in the triune God's mission in all of creation' (Van Gelder \& Zscheile 2011:6), the church is founded in the missio Trinitatis Dei. The church therefore starts in the heart of the Triune God, within his unique being. It is from God's unique being that unconditional love overflows into the world through his different acts to which the church must witness in obedience. This article focuses specifically on God's covenantal acts that always include children (e.g. Noah, Abraham and David). The church is blessed with different gifts (a gift is attached to a person) to be a blessing and is commissioned to celebrate God's love and make it known to the world.

The importance of making the Trinitarian God known in Africa can briefly be described as follows: The first person of the Trinity, God the Father, is often perceived and known in terms of power and perfection, as Creator, Ruler, Lord, King, Almighty, Master and Warrior. These images of God as Father are all conquest- and success-oriented. The second person, Jesus Christ, brings the realisation that God is also merciful, loving, caring and compassionate, a comforter and liberator who shares in our sufferings. Through the grace of Jesus Christ, people are taught to love, forgive and care for one another. Jesus Christ is the 'exact representation of his [God's] being' (Heb 1:3). This love and forgiveness help people to open their lives and to be mutually interdependent. However, it is the third person of the Trinity, the Holy Spirit, who lives within and among us, who guides us and convinces us of sin and redemption (Jn 16), and who witnesses with our spirits that we are children of God ( $\mathrm{Rm} 8$ ). In many instances, especially in Africa, people want a strong God who can save them and they therefore think mostly of God in triumphalistic images. 


\section{Implications of the Trinity for the missional church}

The Soli Deo Gloria principle is of utmost importance for the missional church in Africa, especially when children are involved. When African children realise that all people are created in God's image, they will participate in mission as transformation. This transforms mission from 'mission to the margins' to 'mission from the margins' (cf. Keum 2013). In his discussion on children and the image of God, Towner (2008:318-319) uses Middelton's understanding of a universal Imago Dei that leads to an ethic understanding of 'power with rather than power over'. If the missional church focuses on the Soli Deo Gloria, this principle of 'power with rather than power over' must be the point of departure, especially in Africa with all its power struggles. Knoetze (2015b:5) argues the importance of a good Pateriology for the African children that focuses on the unconditional love of a personal God. A good Pateriology is also important for the missional church in Africa where so many children are fatherless or do not know their fathers. God the Father who is a personal, loving, caring, relational God is the opposite of the Supreme Being in the African traditional religion who is a distant power with no relation to people. In African traditional religion, the ancestors (as the living dead) act as 'intermediaries' between people and the Supreme Being. Oduro et al. (2008:28) remark that when Africans are converted to Christianity, the deep belief in the ancestors does not simply go away. Turaki (2001:243) makes it clear that "All "intermediaries" of African Theology or of any other religions or cultures fall under the superiority of the Person and work of Christ'. The missional church in Africa needs a strong Christological identity with Jesus Christ as the living God of grace who is present through the Holy Spirit. The Holy Spirit empowers the missional church with power to witness (Ac 1:8) and gifts (1 Cor 12; Rm 12) to participate in the missio Dei. A Trinitarian-based missional church will emphasise relationship over product. Bevans and Schroeder (2011:26) in discussing the Trinitarian foundation of the church state: 'Relationship, communion and dialogue, therefore, is the ultimate goal of all existence'.

\section{The missional church is a discerning community}

Zscheile (2012:21-24) specifically uses the concept of discernment to describe God's reign because 'God's reign is now and not yet, hidden but provocatively present' (2012:21). The missional church is not only contextual but also (and more specifically) locally contextual. As the reign of God is discovered and named in our community, we are called to testify it, even in the face of hostility, misunderstanding and persecution. Being part of the grand narrative of God, it is critical that the faith community must answer the question of how they participate in the missional praxis of God in their community. When mission is understood as primarily God's movement, the church is confronted with the significant challenge of discernment (Zscheile 2012:22). This discerning process is, on the one hand, rational and, on the other hand, a mystery. How is it possible to describe the work of the Spirit and of faith seeking understanding? Hendriks (2004:30) refers to this process as correlational hermeneutics, a two-dimensional exegesis of the world and the Word. Discernment happens in the faith community where the interpreted social reality (where the Christian community meets its neighbours in the world) and the interpreted Christian normative sources (Biblical narrative, theological tradition and leading of the Holy Spirit) meet to provide vision for the anticipated future.

Discernment happens with the ultimate human purpose to praise, worship and glorify God. It can only take place within the wondering faith community in worship where the focus is directed to God through the Word and participation in the sacraments. In this process, the Triune God is the one who takes the initiative, with Scripture as the source of revelation:

Luther observed that the Word of God does not arise within one's own heart. It is always an 'external' Word (Verbum externum). It is based on the apostolic witness and proclaimed to us by someone else in the name of God. (Nurnberger 2007:6)

Luther's concern was that what arises from one's own heart may reflect problematic socialisations, self-delusions and desires that need to be challenged and transformed by the Word of God. However:

a faith community is not an archive where members study records about ancient happenings, nor is it an institution that perpetuates bygone structures. It is a community that participates in an ongoing drama, initiated and led by the living triune God. (Hendriks 2004:31)

When a missional congregation works in the context of African spirituality, the discernment of the spirits is of great importance (1 Cor 12:10; 1 Jn 4:1). 'When we have discerned the Holy Spirit's presence, we are called to respond, recognizing that God's Spirit is often subversive, leading us beyond boundaries and surprising us' (Keum 2013:11). In a discernment process, we can never stay the same.

\section{Implications of discernment}

Zscheile (2012:12-14) states it clearly that 'discernment' means 'to discover the reign of God within our midst'. The reign of God is best known through the King of kings and the Lord of lords, Jesus Christ. It is the understanding in this article that discernment is about the Reformed principle that is known as Solus Christus. Scripture is clear that we know Christ through the working of his Spirit (Rm 8:9-17; cf. Keum 2013:9). One of the implications of discernment for the missional church is to engage with the children of Africa in their daily lives: listening to them and listening to the Biblical narrative; wondering with them about God's presence and movement in our lives; and wondering, seeking what God's plan is in the specific context in which they find themselves. Working with African children's spiritual formation, the missional church needs to shape their imagination with the reality of Christ through the working of his Spirit. Zscheile (2012:24) is of the opinion that imagination is shaped by practice ... Spiritual formation happens when we engage in mission. Simultaneously, practices of spiritual formation 
have a missionary dimension'. It is important to listen to and engage with African children and to discern with them (and not for them) the reality of Christ's redemption in their own lives and in Africa. The discernment is not only for their spiritual formation but also to discern God's presence in all areas of their lives, socially, economically, politically, et cetera.

\section{The missional church is committed to evangelism $^{4}$}

The concept 'to evangelise' has been in existence much longer than the word 'mission' and occurs frequently in the New Testament (cf. Bosch 1991:409). Evangelism should be understood as referring to the activities that are involved in spreading the Gospel. '[C]ontroversy prevails in two areas: the differences (if any) between "evangelism" and "mission," and the scope or range of evangelism' (Bosch 1991:409). Mission should be wider than evangelism; therefore, to be a missional church is more than just being involved in evangelism, although a church cannot be missional without evangelism. The latter must be seen as witnessing to the God story, to what God has done, is doing and will do, and to invite the listeners to recognise and choose to participate actively in this story. Although the effectiveness of evangelism cannot be defined in terms ofitsresults, itdoesaimata response(Bosch1991:412-413). Evangelism is not about building bridges. It is also not about constructing some artificial connection with children in a distant land. Evangelism is committed to proximity and time. 'It means getting in the canoe and crossing the "waterways of life" together, in community with your sphere of relationships' (Folmsbee 2007:31). The (church as) evangelist is only a witness and not a judge, and evangelism is only possible where Christian faith is manifested and an attractive lifestyle is exhibited. 'Without the church there can be no evangelism or mission' (Bosch 1991:416).

Evangelism should never focus on the church; it is not about church extension, membership recruitment or proselytism (Bosch 1991:414-416). Evangelism is about the irrupting of the reign of God, offering people salvation as a present gift. 'It is not simply to receive life that people are called to become Christians, but rather to give life' (Bosch 1991:414). Therefore, authentic and costly evangelism may cause a church's membership to decline rather than increase. Despite the fact that the missional church wants to influence society and unjust structures, only people can be addressed and only people can respond in evangelism; this does not make the Gospel individualistic, though. Especially in Africa, people are never isolated individuals, but exist within a network of relationships. Within the context of welcoming the African child, the social group (family and parents) must be involved in the engagement with the child, whether they approve of it or not. Evangelism that separates people from their context does not view the world as a challenge, but as a hindrance and, thus, devalues history (Bosch 1991:417). Evangelism is therefore also about the practising of justice as it is revealed in the Bible:
God wills not only that we be rescued from hell and redeemed for heaven, but also that within us - and through our ministry also in society around us - the 'fullness of Christ' be recreated, the image of God be restored in our lives and relationships. (Bosch 1991:418)

In the missional church, people are called to service in word and deed.

\section{Implications of evangelism for the missional church}

The foremost implication of evangelism for the missional church is to live our faith in the grace of the Trinitarian God and not to act as judges. This article argues that the Sola Fide principle is an essential concept for evangelism. Bediako (1995:162) remarked that 'we know Jesus the truth by following Jesus the way'. Evangelism takes place when believers participate in the missio Dei obediently, acting as witnesses and facilitators of people's own discovery of their heritage as children of Abraham (cf. Bediako 1996:187). The implication of evangelism for the missional church is living our faith by discerning God's reign in our everyday life, helping each other to see God's reign with and through one another. 'The Gospel invitation is to a relationship, not just intellectual assent or agreement to a set of ideas' (Myers 2011:311). Evangelism is also more than just stating your faith: it is the proclamation of God's reign here and now (cf. Brueggemann 1993). Evangelism with children must first focus on the person of the child and not on issues relating to the child.

\section{The missional church is a hermeneutic community}

The break in the relationship between man and God was an effective break and man cannot get back to God on his own. Man needs God to know God. In the grand narrative of God, it is clear that God wants to be known; he therefore initiated the covenant, revealed himself in Jesus Christ the Redeemer and sent the Spirit to guide and equip the faith community in his mission. The church as hermeneutic community 'reads the biblical story as its story and applies this story to the concrete circumstances of its time, place and culture' (Myers 2011:200). God is always at work to bring insight to his own by means of the covenant community. According to Myers, 'this is the community within the community from which the word of God is heard, lived and revealed'. God wants to bless the world through those adults and children who participate in the covenant. He granted them a hermeneutic function. The covenant community only fulfil this hermeneutic function when they are ethically obedient. When Paul wrote to the Romans, he described his calling in Romans 1:15 as 'to bring about the obedience of faith for the sake of his name among all the nations' (cf. Schirrmacher 2013:50; Wright 2010:63). It is only in obedience to the Triune God that the covenant community as ethical community can fulfil their hermeneutical function (cf. Wright 2006:357-392).

Departing from the covenant, it is clear that God works in the realm of relations, and the relations between 'parents and 
children are the most natural of these relationships' (Nel 2000:21). When the relationships in the family are deficient for whatever reason, the principle that God works within relationships is not abandoned. In the African culture, the concept of the extended family is well known and practised. The hermeneutical sphere of the congregation as an 'extended family' is an unnoticed and underutilised support system. In a unique way, God is known in the hermeneutical sphere of the congregation where lived and shared faith plays an important role in the insight of the next generation and those who are 'not yet part' of his kingdom.

God's new work and revelation in mission is also an old work and revelation because the church is not shaped primarily by the spirit of the 1950s, the 1990s or 2015, but by the eternal Spirit who has been shaping and sending witnesses to the Gospel for thousands of years (Billings 2008:59).

\section{Implications of being a hermeneutic community}

One of the implications of being a hermeneutic community in Africa is that the missional church needs an experimental ministry in which an ongoing dialogue is taking place between text and context, a ministry that remains provisional and hypothetical (cf. Bosch 1991:427). Being a hermeneutic community implies that the focus is on God; it is him that the missional church wants to make known. We may therefore link the hermeneutic implication with the Reformed principle of Soli Deo Gloria.

Hendriks (2004:24) talks about a fundamental shift in practising theology. The shift is from 'obediently analysing and systematising' our faith tradition to 'participating obediently' in God's missional praxis (with children). The shift is from the church focusing on their knowledge about God to an 'experimental' faith seeking, focusing on God and an involvement in his revelation within the context of African children. The missional church as hermeneutic community does not come from a power position to African children, but as a participant and servant in dialogue. Describing this kind of dialogue, Bevans and Schroeder (2011:33) call it 'prophetic dialogue' and use the image of entering into someone else's garden:

to appreciate another way of gardening, another way of arranging the flower beds or vegetable patches, another way of pruning and weeding. One can always learn from another gardener, and although one may want to give advice for growing roses or tomatoes, it is probably best that one waits until asked. (p. 33)

As a hermeneutic community, the missional church's purpose is to discover God mutually through words and deeds with the children in order that lives will be transformed to recover true identity and discover true vocation. In this regard, the missional church must be clear in its ministry that the Sunday school and sacraments are not just rituals of the faith community, but are about Soli Deo Gloria, true identity and belonging, because rituals in Africa are in many instances clear demarcations (that can be walls or fences, or be invisible) between 'inside' (belonging to the group) and 'outside' (not part of the group). The focus of the sacraments is specific that we belong to and are part of the God story. That is our identity.

\section{The missional church is an agogic (transformative) community}

When the missional church is described as an agogic or transformative community, we must answer with what the Church believes people must be transformed from and transformed to (cf. Knoetze 2015c), even more so when we talk about children. It is true of all people that sin has a continuing identity deception, distraction and distortion. All people need to be transformed to their recreated identity in Christ. Transformation is thus about our relationships with God, people and nature. The gathering of the congregation is the gathering of people in transition because they are new people in Christ. No one is ever finished or completely transformed in the sense of changed into perfection:

This constant change (conversion) to the reality already granted by God is the central agogic principle in Scripture. God has finished creating, but he is not yet finished with his creation. (Nel 2000:22)

Constant change in the missional church is normal within the gathering of people who have been changed by their calling. In creating the congregation, God has created the sphere for change (cf. Nel 2000:23). Within the missional church, conversion may no longer be a fundamental change, rather a process of becoming aware of new insights and choices. It is also a process of becoming aware of those who are the 'other' to us and are not yet part of the reconciled community. In the faith community, change can only be understood pneumatologically. The document of the WCC, entitled 'Together towards life', states that 'mission spirituality is always transformative. Mission spirituality resists and seeks to transform all life-destroying values and systems wherever these are at work ....' (Keum 2013:13). In many instances, these changes to become what we are in Christ are not without difficulty and pain. Within the missional church, it is not only normal to change, but the missional church motivates and facilitates growth and change. For people to change, others are needed; we need the Wholly Other, and we also need those who have been changed by him.

\section{Implications of a missional church as an agogic community}

The first and foremost implication of the missional church as an agogic community is the continuous grace of God. The Sola Gratia principle is fundamental in understanding the missional church as a transformative community. When one views the missional church as a 'becoming' community, it can be stated that it is the safest place for African children to rediscover their identity through and within the grace of God. The new identity has everything to do with where people come from and who they have become in Christ. Africa's children must be helped to remember that they come 
from Africa, that they are Africans and that they are recreated, like all other people in the world, in the image of God. The implication is that the missional church in Africa needs to be contextual to the needs of Africa and should participate in the faith seeking of Africa's children to become who God created them to be in a community where everyone is still 'becoming' what they already are in Christ.

\section{Conclusion}

'Missional', as used in this article to 'represent[s] a changed relationship between the church and its local context, one that calls for a renewed understanding of the church's identity in God' (Van Gelder \& Zscheile 2011:1), calls for closer relationships between the MMCs and the AICs for both to become more missional. The identity of the missional church is best understood from the perspective of the Trinitarian God as Creator, Redeemer and Comforter. The discussion on the nature and implications of the missional church further indicates, in general, the interdependence between the MMCs and the AICs. The MMCs need the AICs to become more contextual and the AICs need the MMCs to become more Biblical for both to be more of a hermeneutical community. It is also clear from the discussion that a missional church has strong reformational roots; however, if it wants to be contextual to Africa, it cannot be an institutionalised church; it needs to be an organic church, an agogic community. Of even more importance is the fact that they need each other to welcome the children of Africa and help them to rediscover their identity, finding through evangelism that they have always been part of God's story with creation. As a missional book, the Bible teaches about the centrality of the Kingdom of God; may the church in Africa keep on praying, 'Let your Kingdom come'.

\section{Acknowledgements Competing interests}

The author declares that he has no financial or personal relationships which may have inappropriately influenced him in writing this article.

\section{References}

Adogbo, M.P., 2005, 'Methodological problems in the study of African traditional religions', Journal of Theology for Southern Africa 122, 76-83.

Allen, M., 2013, 'What a missional church looks like', in S.T. Logan (ed.), Reformed means missional: Following Jesus into the world, pp. 11-22, New Growth Press, Greensboro, NC

Anderson, G.H. (ed.), 1961, The theology of the Christian mission, SCM Press Ltd. London.

Bediako, K., 1995, Christianity in Africa: The renewal of a non-Western religion, Orbis Books, Maryknoll, NY.

Bediako, K., 1996, 'Theological reflections', in T. Yamamori, B.L. Myers \& D. Conner (eds.), Serving with the poor in Africa: Cases in holistic ministry, MARC, Monrovia, CA.

Bevans, S.B. \& Schroeder, R.P., 2011, Prophetic dialogue: Reflections on Christian mission today, Orbis Books, Maryknoll, NY.
Billings, J.T., 2008, 'What makes a church missional? Freedom from cultural captivity does not mean freedom from tradition', Christian Today, March 2008, 56-59.

Bosch, D.J., 1991, Transforming mission: Paradigm shifts in theology of mission, Orbis Books, Maryknoll, NY.

Brueggemann, W., 1993, Biblical perspectives on evangelism: Living in a three-storied universe, Abingdon Press, Nashville, TN.

Bunge, M.J. (ed.), 2008, The child in the Bible, William B. Eerdmans Publishing Company, Grand Rapids, MI.

Dean, K.C., 2001, 'Fessing up: Owning our theological commitments', in K.C. Dean, C. Clark \& D. Rhan (eds.), Starting right: Thinking theologically about youth ministry, pp. 27-39, Zondervan Publishing House, Grand Rapids, MI.

Ducker, C., 2008, 'Explain the thinking behind mission as missio Dei', viewed 26 January 2016, from http://www.theduckers.org/media/missiodei.pdf

Engelsviken, T., 2003, 'Missio Dei: The understanding and misunderstanding of a theological concept in European churches and missiology', International Review of Mission 92(367), 481-496. http://dx.doi.org/10.1111/j.1758-6631.2003.tb00424.x

Folmsbee, C., 2007, A new kind of youth ministry, Zondervan, Grand Rapids, MI.

Hendriks, H.J., 2004, Studying congregations in Africa, Lux Verbi, Wellington.

Heyns, J.A., 1978, Dogmatiek, N.G. Kerkboekhandel, Pretoria.

Keum, J. (ed.), 2013, Together towards life: Mission and evangelism in changing landscapes (with a practical guide), WCC Publications, Geneva.

Knoetze, H., 2015a, 'Together towards life and Evangelii Gaudium: Implications for African Child Theology today', Missionalia 43(2), 218-231. http://dx.doi. org/10.7832/43-2-96

Knoetze, J.J., 2015b, 'Perspectives on family and youth ministry embedded in the missio Dei - An African perspective', In die Skriflig 49(1), Art. \#1874, 9 p.

Knoetze, J.J., 2015c, 'Spiritual transformation: Reaching and equipping Sub-Saharan African children', In die Skriflig 49(1), Art. \#1919, 8 p.

Miller, P.D., 2008, 'That the children may know: Children in Deuteronomy', in M.J. Bunge (ed.), The child in the Bible, pp. 45-62, William B. Eerdmans Publishing Company, Grand Rapids, MI.

Myers, B.L., 2011, Walking with the poor: Principles and practices of transformationa development, Orbis Books, Maryknoll, NY.

Ndukwe, O., 2011, Among the nations: Rebranding the Christian church for a disappointed world, Agbotech, Enugu, Nigeria.

Nel, M., 2000, Youth ministry: An inclusive congregational approach, Design Books, Clubview.

Nurnberger, C., 2007, The living dead and the living God, Cluster Publication, Pietermaritzburg.

Oduro, T.A., 2014, “'Arise, walk through the length and breadth of the land”: Missionary concepts and strategies of African Independent Churches', International Bulletin of Missional Research 38(2), 86-89. http://dx.doi.org/10.1177/239693931403800211

Oduro, T.A., Pretorius, H., Nussbaum, S. \& Born B., 2008, Mission in an African way: A practical introduction to African Instituted Churches and their sense of mission, CLF, Wellington.

Saayman, W., 2010, 'Missionary or missional? A study in terminology', Missionalia 38(1), 5-16.

Schirrmacher, T., 2013, 'The book of Romans and the missional mandate: Why mission and theology must go together', in S.T. Logan (ed.), Reformed means missional: Following Jesus into the world, pp.48-63, New Growth Press, Greensboro, NC.

Towner, W.S., 2008, 'Children and the image of God', in M.J. Bunge (ed.), The child in the Bible, pp. 307-323, William B. Eerdmans Publishing Company, Grand Rapids, MI.

Turaki, Y., 2001, The unique Christ for salvation: The challenge of the non-Christian religions and cultures, International Bible Society Africa, Nairobi, Kenya.

Van der Walt, B.J., 2008, The eye is the lamp of the body: Worldviews and their impact, The Institute for Contemporary Christianity in Africa (ICCA), Potchefstroom.

Van Gelder, C. \& Zscheile, D.J., 2011, The missional church in perspective: Mapping trends and shaping the conversation, Baker Academic, Grand Rapids, MI.

Wright, C.J.H., 2006, The mission of God: Unlocking the Bible's grand narrative, InterVarsity Press, Downers Grove, IL.

Wright, C.J.H., 2010, The mission of God's people: A Biblical theology of the church's mission, Zondervan, Grand Rapids, MI.

Wright, C.J.H., 2013, 'What do we mean by “missional”?', in S.T. Logan (ed.), Reformed means missional: Following Jesus into the world, pp. ix-xiii, New Growth Press, Maryknoll, NY

Zscheile, D.J. (ed.), 2012, Cultivating sent communities. Missional Spiritual formation, William B. Eerdmans Publishing Company, Grand Rapids, MI. 